Review

\title{
Nanosized molecular sieves as petroleum refining and petrochemical catalysts
}

\author{
MU Xuhong *, WANG Dianzhong, WANG Yongrui, LIN Min, CHENG Shibiao, SHU Xingtian \\ State Key Laboratory of Catalytic Materials and Reaction Engineering, Research Institute of Petroleum Processing, SINOPEC, Beijing 100083, China
}

\section{A R T I C L E I N F O}

\section{Article history:}

Received 25 July 2012

Accepted 24 September 2012

Published 20 January 2013

\section{Keywords:}

Nanosized molecular sieve

Gasoline reforming

Ethylbenzene

Caprolactam

\begin{abstract}
A B S T R A C T
Nanosized ZSM- 5 was synthesized and used for straight run gasoline reforming. Nanosized $\beta$ was synthesized and used for the alkylation of benzene and ethylene in ethylbenzene production. Nanosized titanosilicate molecular sieve with a hollow structure (HTS) was synthesized and used for the oximation of cyclohexanone. Nanosized silicalite- 1 was synthesized and used for the gas phase Beckmann rearrangement of cyclohexanone oxime in caprolactam production. Recent progress in the synthesis and application of nanosized ZSM-5, $\beta$, TS-1, and silicalite- 1 were reviewed. The catalyst lifetimes were prolonged when nanosized molecular sieves were used as petroleum refining and petrochemical catalysts.
\end{abstract}

(C) 2013, Dalian Institute of Chemical Physics, Chinese Academy of Sciences. Published by Elsevier B.V. All rights reserved.

\section{Introduction}

Zeolites are widely used as catalysts in the oil refining and petrochemical industries for fluid catalytic cracking, hydrocracking, gasoline and diesel reforming, lube oil hydroprocessing, olefin oligomerization, production of light olefins, isomerization of xylene, ethylbezene and cumene production, selective oxidation, etc [1]. Nanosized zeolites show higher catalytic activities than conventional zeolites because their small crystals have more active sites. In addition, the selectivity in some reactions is improved and coke formation is prevented, which gives a longer catalyst lifetime because of less diffusion limitation of reactants and products in the small crystals. Therefore, the synthesis and application of nanosized zeolites have been actively studied. The Research Institute of Petroleum Processing (RIPP), SINOPEC has been engaged in the research of nanosized Y, ZSM-5, and $\beta$ zeolites since the 1990s to solve the difficulties in their industrial production and applications, such as their synthesis, filtration, and dispersion, and RIPP has developed several refining and petrochemical catalysts. This paper gives a summary of the synthesis and application of four nanosized zeolites, namely, (1) nanosized ZSM-5 synthesis and its application in straight run gasoline reforming, (2) nanosized $\beta$ synthesis and its application in the alkylation of benzene and ethylene for ethylbenzene production, (3) synthesis of nanosized titanosilicate molecular sieve with a hollow structure (HTS) and its application in the oximation of cyclohexanone, and (4) nanosized silicalite-1 synthesis and its application in the gas phase Beckmann rearrangement of cyclohexanone oxime for caprolactam production.

\section{Synthesis of nanosized ZSM-5 and its application in straight run gasoline reforming}

Straight run gasoline reforming is an oil refining process in which straight run gasoline and C4 distillates are converted into high octane number gasoline and high quality liquid petroleum gas by selective cracking, isomerization, oligomerization, cyclization, and aromatization [2]. The catalyst used in this process is ZSM-5 zeolite. However, the stability of the activity is

\footnotetext{
* Corresponding author. Tel: +86-10-82368237; Fax: +86-10-62311290; E-mail: muxuhong.ripp@sinopec.com This work was supported by the National Basic Research Program of China (973 Program, 2012CB224805). DOI: 10.1016/S1872-2067(11)60462-2
} 
Table 1

Physicochemical properties of zeolite ZSM-5 [11].

\begin{tabular}{|c|c|c|c|c|c|c|}
\hline \multirow{2}{*}{ Sample } & \multicolumn{3}{|c|}{ Surface area $\left(\mathrm{m}^{2} / \mathrm{g}\right)$} & \multicolumn{2}{|c|}{ Pore volume $\left(\mathrm{cm}^{3} / \mathrm{g}\right)$} & \multirow{2}{*}{$\begin{array}{l}\text { Crystal } \\
\text { size }(n m)\end{array}$} \\
\hline & BET & Int. & Ext. & Total & Micropore & \\
\hline $\begin{array}{l}\text { Nanosized } \\
\text { ZSM-5 }\end{array}$ & 422 & 330 & 92 & 0.320 & 0.152 & $50-100$ \\
\hline $\begin{array}{l}\text { Conventional } \\
\text { ZSM-5 }\end{array}$ & 354 & 344 & 10 & 0.182 & 0.160 & $800-1500$ \\
\hline
\end{tabular}

Int.-Internal; Ext.-External.

poor, which results in short operational periods. The reason for the deactivation is coke formation on the catalyst. Recently there were many reports on improving the activity and prolonging the lifetime by using ZSM-5 with a smaller crystal size. Visvanadham et al. [3] lengthened the lifetime of the catalyst in the reaction of ethanol to ethylene by reducing the crystal size to the submicron range. Tago et al. [4] synthesized ZSM-5 in the size range of 30-40 $\mathrm{nm}$ by an emulsion method and used these in the process that converts acetone to light olefins. The activity and lifetime of the catalyst were much improved compared with ZSM-5 with a large crystal size. Ni et al. [5] reported that conventional ZSM-5 as the catalyst in the aromatization of methanol deactivated quickly, but with nanosized ZSM-5 as the catalyst, coke formation was prevented and the lifetime of the catalyst was prolonged. Miao et al. [6] prepared ZSM-5 zeolite nanoclusters from seeds functionalized with organosilane and reported that the nanosized ZSM-5 zeolite gave a much higher activity than conventional ZSM-5 in the benzylation reaction of 1,2,3-trimethyl benzene, which was due to the decrease of the diffusion limitation of large molecules resulting from the small crystal size. Since a nanosized zeolite exposes more active sites and possesses shorter diffusion routes, which all help prolong catalyst life, we investigated the synthesis of nanosized ZSM-5 and its application in straight run gasoline reforming.

\subsection{Synthesis and properties of nanosized ZSM-5}

The crystal size of the zeolite can be controlled by the ratio of the nucleation rate and growth rate during synthesis. When the rate of nucleation is higher than the rate of growth, a small-sized zeolite is obtained. For this purpose, there are many synthesis methods reported in the literature, such as

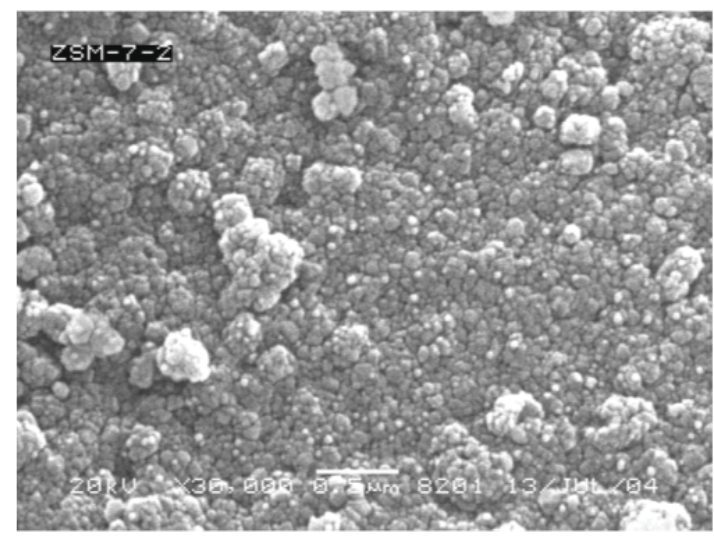

Fig. 1. SEM image of nanosized ZSM-5 [11].

controlling the crystallization temperature, time, and the usage of alkali and template, using organic Si and Al sources, use of the clear solution method and the emulsion method, and synthesis in a confined space [3-9]. Since most methods reported in the literature are expensive and are not suitable for industrial production and application, we chose to prepare nanosized ZSM- 5 by the multistage crystallization method by using seeds and controlling the nucleation and crystallization temperatures [10].

Table 1 compares the physicochemical properties of nanosized and conventional ZSM-5. The nanosized ZSM-5 has a higher surface area, especially the external surface area, and a similar volume of micropores but a larger volume of mesopores in comparison to conventional ZSM-5. These results imply that the synthesized sample has a small crystal size and possesses mesopores formed by particle aggregation. Figure 1 is the SEM image of the nanosized ZSM-5, which shows that the crystal sizes are very uniform and in the range of 50-100 nm.

\subsection{Catalytic performance of nanosized ZSM-5 catalyst in straight run gasoline reforming}

Figure 2 shows the performance of the nanosized ZSM-5 catalyst in the process of straight run gasoline reforming. The reaction conditions were LHSV $=0.3-0.5 \mathrm{~h}^{-1}$, temperature 320 $440{ }^{\circ} \mathrm{C}$, and pressure $0.2-0.4 \mathrm{MPa}$. Compared to a conventional ZSM-5 catalyst, the nanosized ZSM-5 catalyst gave a similar
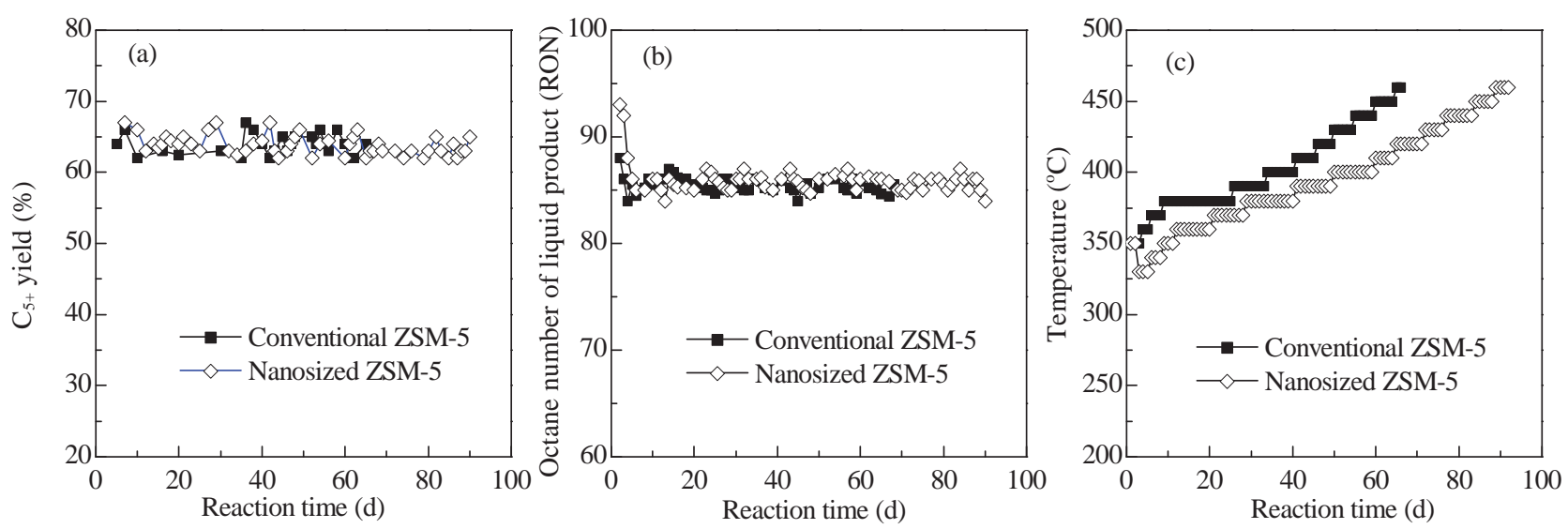

Fig. 2. Catalytic activities in gasoline reforming [11]. 
liquid product $\left(\mathrm{C}_{5^{+}}\right)$yield and research octane number (RON), but the initial reaction temperature was lowered, which led to a larger operation range and longer operational periods from 60 d to more than $90 \mathrm{~d}$.

\section{Synthesis of nanosized $\beta$ zeolite and its application in the alkylation of benzene with ethylene}

Ethylbenzene is the feed material for the production of styrene, which is widely used in the production of polystyrene, butadiene styrene rubber, ABS resin, and SBS plastics. In early times, ethylbenzene was produced using $\mathrm{AlCl}_{3}$ as catalyst. Due to the problem of corrosion, it was replaced by a ZSM-5 catalyst and a gas phase alkylation process. Then, liquid phase alkylation technologies using $\beta$ or MCM-22 catalysts were developed. With the improvement of the catalyst, the consumption of energy and feed materials were reduced, the quality of the ethylbenzene product was improved, and the operational periods became longer. RIPP has been engaged in the development of liquid phase alkylation of benzene with ethylene since the 1990s. The AEB-2 catalyst using $\beta$ zeolite was developed [12-14]. In order to increase the activity and lifetime of the catalyst, we synthesized nanosized $\beta$ zeolite and used it as the catalyst in the alkylation of benzene with ethylene for ethylbenzene production.

\subsection{Synthesis and properties of nanosized $\beta$ zeolite}

There were reports of nanosized $\beta$ synthesis even in the 1990s. In the early times, research was focused on using organic $\mathrm{Si}$ and $\mathrm{Al}$ sources, using more template amounts and decreasing the crystallization temperature to make the crystal size of $\beta$ zeolite smaller. Recently there have been reports of new synthesis methods, such as the steam assisted method [15], the dry gel method [16] , and one-step synthesis of mesoporous $\beta$ zeolite using phosphate [17]. We synthesized $\beta$ zeolite using solid silica gel as the $\mathrm{Si}$ source, $\mathrm{NaAlO}_{2}$ as the $\mathrm{Al}$ source, and TEAOH as the template. In the process of synthesis, first, some solid silica gel disaggregates into polysilicate anions in the strong alkali system. Then, the silicate and aluminate combine due to the action of the template. After aggregation and dehydration, nuclei are formed. After that, the solid silica gel disaggregates gradually and goes into the liquor for further crystallization to form the precursor of the $\beta$ zeolite, which is ordered on the short range but disordered on the long range. Finally, the nuclei grow into $\beta$ crystals. In order to reduce the crystal size of the $\beta$ zeolite, we used the multistage method to form the nuclei at a lower temperature and to grow these at a higher temperature. Meanwhile, the polymerization degree of the silica gel was controlled to make it disaggregate easily to

Table 2

Physicochemical properties of zeolite $\beta$.

\begin{tabular}{lccccccc}
\hline \multirow{2}{*}{ Sample } & \multicolumn{3}{c}{ Surface area $\left(\mathrm{m}^{2} / \mathrm{g}\right)$} & & \multicolumn{2}{c}{ Pore volume $\left(\mathrm{cm}^{3} / \mathrm{g}\right)$} & Crystal \\
\cline { 2 - 3 } & BET & Int. & Ext. & & Total & Micropore & size $(\mathrm{nm})$ \\
\hline Nanosized $\beta$ & 650 & 554 & 96 & & 0.640 & 0.189 & $30-50$ \\
Conventional $\beta$ & 554 & 487 & 67 & & 0.348 & 0.184 & $55-130$ \\
\hline
\end{tabular}

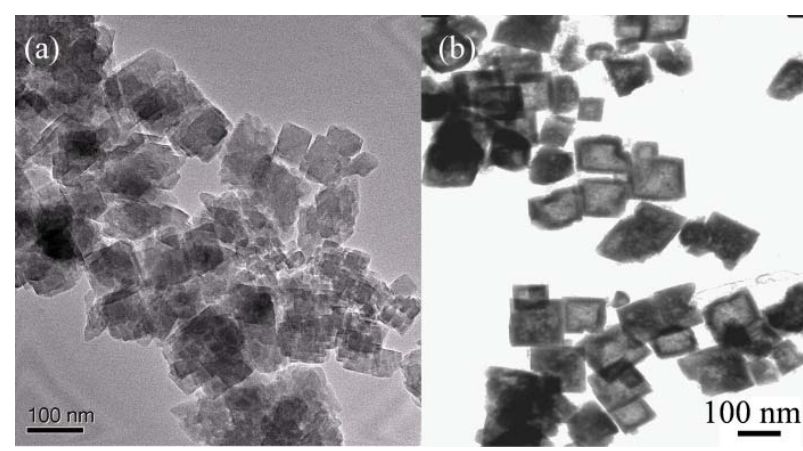

Fig. 3. TEM images of nanosized $\beta$ (a) and conventional $\beta$ (b).

silicate anions under the alkaline conditions. These silicate anions reacted with aluminate quickly to form many nuclei in a very short time. In this way, the rate of nucleation was faster than that of the growth, and nanosized $\beta$ was obtained.

Table 2 gives the surface area and pore volume of the nanosized and conventional $\beta$ zeolites. The surface area and pore volume of the nanosized $\beta$ were larger than those of conventional $\beta$, which imply a small crystal size of the nanosized $\beta$. The TEM images in Fig. 3 verify these results.

Figure 4 shows the $\mathrm{SiO}_{2} / \mathrm{Al}_{2} \mathrm{O}_{3}$ ratio of six nanosized crystals at different positions along the diagonal line measured by EDX. In Fig. 4, the numbers 1 and 8 on the horizontal axis denote the two opposite ends of the diagonal line of the crystal, the numbers 2 to 7 denote six equal interval positions on the diagonal line of the crystal, and the vertical axis shows the $\mathrm{SiO}_{2} / \mathrm{Al}_{2} \mathrm{O}_{3}$ ratio. The figure shows that the $\mathrm{SiO}_{2} / \mathrm{Al}_{2} \mathrm{O}_{3}$ ratio of the surface was higher than that of the center of the crystal. The six crystals have the same trend. This result implied that the nanosized $\beta$ synthesized was surface enriched in $\mathrm{Si}$, which helped improve the selectivity of the $\beta$ zeolite catalyst.

\subsection{Catalytic performance of the nanosized $\beta$ catalyst in the alkylation of benzene with ethylene}

The catalytic performance of the nanosized and conventional $\beta$ catalysts in the alkylation of benzene with ethylene was evaluated in a fixed-bed reactor. Catalyst $(8 \mathrm{ml})$ with particle sizes of 16-20 mesh was used. The reaction temperature was

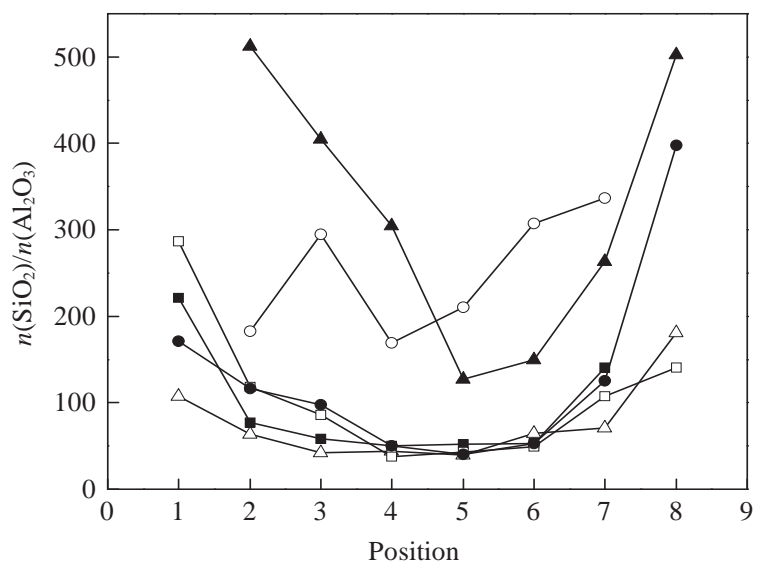

Fig. 4. $\mathrm{SiO}_{2} / \mathrm{Al}_{2} \mathrm{O}_{3}$ ratio at different positions in the six nanosized $\beta$ zeolite crystals. 
$250{ }^{\circ} \mathrm{C}$ and the pressure was $3.5 \mathrm{MPa}$. In the experiment, the catalyst was first evaluated with a benzene LHSV of $3 \mathrm{~h}^{-1}$ and benzene/ethylene molar ratio at 12 for $100 \mathrm{~h}$, then evaluated at a benzene LHSV of $12 \mathrm{~h}^{-1}$ and benzene/ethylene molar ratio at 18 for another $100 \mathrm{~h}$ or $200 \mathrm{~h}$. The results are shown in Fig. 5. With the nanosized $\beta$ catalyst and the lower space velocity, the selectivity for ethylbenzene was $95.4 \%$, the selectivity for ethylization was $99.4 \%$, and the conversion of ethylene was $100 \%$, while at the higher space velocity, the selectivity for ethylbenzene was $96.7 \%$, the selectivity for ethylization was $99.5 \%$ and the conversion of ethylene was $100 \%$. For conventional $\beta$ catalyst, at the lower space velocity, the selectivity for ethylbenzene was $95.4 \%$, the selectivity for ethylization was $99.4 \%$ and the conversion of ethylene was $100 \%$, while at the higher space velocity, the selectivity for ethylbenzene was $96.9 \%$, the selectivity for ethylization was $99.5 \%$ and the conversion of ethylene was $100 \%$. The two catalysts gave the same performance in the alkylation of benzene with ethylene. However, the nanosized $\beta$ catalyst gave a longer run time. When used industrially, the operation period was prolonged from 3 years to 5 years.

\section{Synthesis of nanosized titanium silicalite with a hollow structure (HTS) and its application in the oximation of cyclohexanone}

Caprolactam is an important monomer for producing nylon- 6 engineering plastics and fibers. Nylon- 6 engineering plastics are used in the electronics, automobile, and packing industries. Nylon-6 fibers are used in the knitting and weaving industries. With the fast growth of the automobile and weaving industries in China, the demand for caprolactam has increased steadily. The major routes for caprolactam production include benzene hydrogenation, cyclohexane oxidation, cyclohexanone oximation, and cyclohexanone oxime to caprolactam by Beckmann rearrangement and some unit operations of the purification of caprolactam. The conventional technology for cyclohexanone oximation is the so-called HPO method in which four reactions are needed. The technology not only has a complicated flow chart but also gives $\mathrm{NO}_{x}$ emission, which results in environmental problems. EniChem has synthesized a TS-1 molecular sieve and used it as the catalyst for cyclohexanone oxi- mation with ammonia and $\mathrm{H}_{2} \mathrm{O}_{2}$ to produce cyclohexanone oxime. This route is environmentally friendly. However, the TS- 1 catalyst deactivates rapidly. Research has shown that the reason for the deactivation is that the pore mouth is easily blocked by the heavy products $[18,19]$. Once the activity of the catalyst has decreased to some extent, the conversion of the main reaction decreases quickly, and meanwhile, the decompositon of $\mathrm{H}_{2} \mathrm{O}_{2}$ occurs, which would cause safety problems. RIPP has worked on solving these problems using the synthesis of titanosilicate molecular sieve with the controlling of the crystal size and morphology.

\subsection{Synthesis and properties of titanosilicate molecular sieve with hollow structure (HTS)}

There have been many reports on the synthesis of TS- 1 since its discovery in the 1980s. Owing to the difference in the atomic radius and electron structure of $\mathrm{Ti}$ and $\mathrm{Si}$, it is difficult to get Ti tetrahedrally coordinated into the framework of the molecular sieve. The reproducibility of the synthesis is poor, and so it is difficult to get TS-1 with high activity and stable properties. Although many companies have performed much research, only EniChem has the technology for TS-1 commercial production and application. TS-1 shows good activity for oxidation but the lifetime is not long enough, which is due to its small pore size that leads to diffusion resistance. This is why TS- 1 has not been used widely. In order to solve this problem, researchers have done much work in synthesizing new materials with larger pores, such as Ti-MWW, Ti- $\beta$, Ti-MCM-41, and Ti-SBA-15. Ti-MCM-22 shows good activity for the oxidation of larger molecules after some modifications have been made based on its lamellar structure [20]. The last three materials have poor hydrothermal stability and activity. Recently, there have been many reports on TS-1 with a hierarchical pore structure. Hierarchical TS-1 has been prepared by using porogenic agents, by a self-assembly method under controlled water evaporation of a colloidal suspension containing TS-1 nanocrystals, and by two-step crystallization using silanization agents [21-23]. RIPP has synthesized titanosilicate molecular sieve with a hollow structure (HTS) using a crystallization and post treatment method. By studying the mechanism of HTS synthesis [24-27], new ideas have been tested to ensure the suitable hydrolysis of
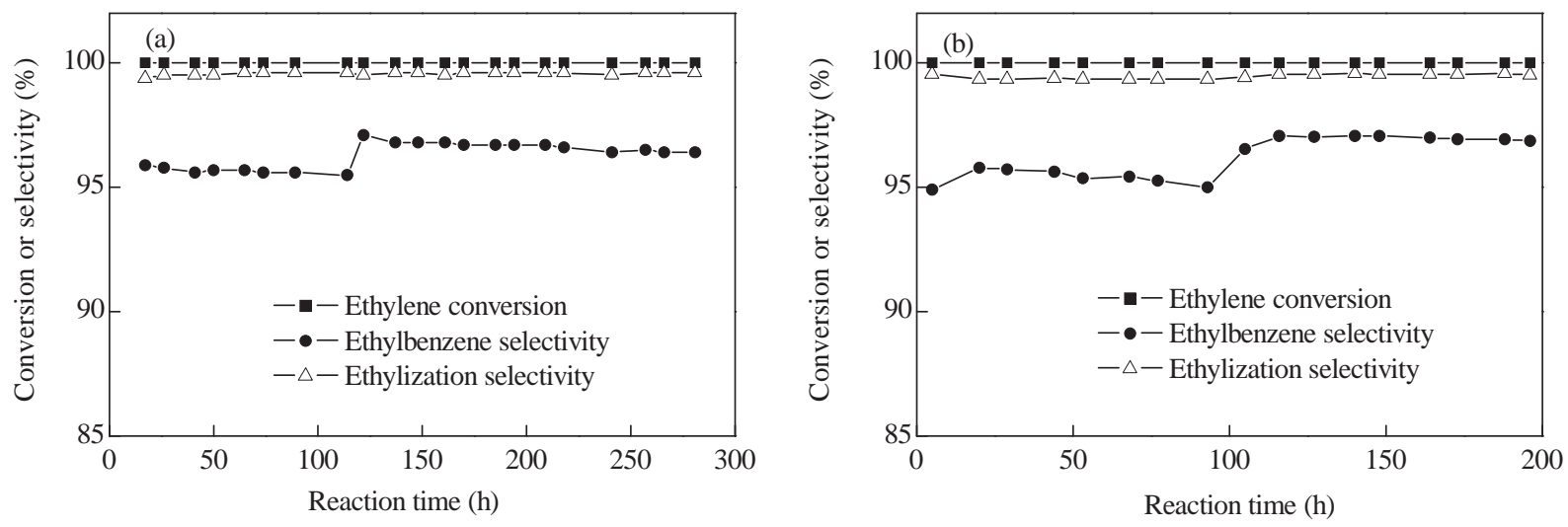

Fig. 5. Catalytic properties of nanosized $\beta$ catalyst (a) and conventional $\beta$ catalyst (b) for the alkylation of benzene and ethylene. 
tetraethylorthosilicate (TEOS) and tetraethylorthotitanate (TEOT), and complete nucleation during the period of removing alcohol. By controlling the hydrolysis of TEOS and TEOT, the rates to form $\mathrm{Si}$ and Ti species were kept consistent. Then, nuclei were formed with the help of the template in the process of alcohol removal. The crystal size of the molecular sieve was controlled to less than $100 \mathrm{~nm}$ by multistage crystallization at different temperatures. In the process, the pre-crystallized molecular sieve undergoes structural reconstruction due to the action of the organic amines and other surfactants. This step guaranteed the reproducibility of the molecular sieve by enhancing the condensation reaction between the Ti and Si species and promoting the incorporation of non-framework Ti into the framework, which leads to more active sites. In this step, the morphology of the molecular sieve was also changed and a hollow structure was formed in the crystals. The nanosized crystals and hollow structure helped the fast diffusion of reactants and products, which then inhibits the deactivation of the catalyst that would have been caused by the blockage of the pores.

Figure 6 shows the adsorption-desorption isotherms obtained with the HTS and TS-1 molecular sieves. There was a big hysteresis loop in the isotherm of HTS, which indicated the presence of mesopores. In contrast, TS- 1 gave a Type I isotherm, which indicated only the existence of micropores.

Due to its small size and hollow structure, HTS showed less diffusion limitation and a longer lifetime in the ammoximation of cyclohexanone. However, HTS was difficult to filtrate and recycle when it was used in the industrial process. We have prepared assemblies of HTS by adjusting the conditions of the synthesis system. As shown in Fig. 7, these assemblies of HTS were uniform in size and were $300-500 \mathrm{~nm}$, and could be filtrated and reused easily.

\subsection{Catalytic performance of HTS in the ammoximation of cyclohexanone}

Figure 8 shows the dependence of cyclohexanone conversion on time in the ammoximation of cyclohexanone. The reaction temperature was $83^{\circ} \mathrm{C}$, and the pressure was $0.4 \mathrm{MPa}$. The

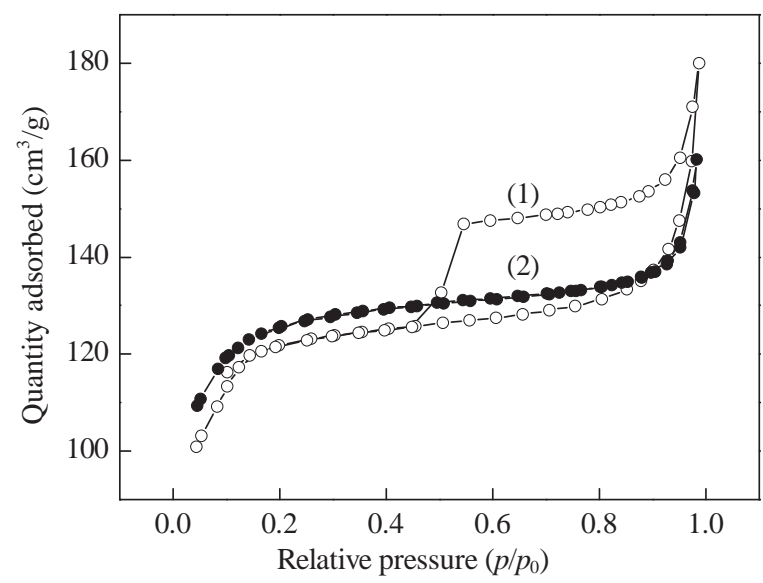

Fig. 6. $\mathrm{N}_{2}$ adsorption-desorption isotherms of HTS (1) and conventional TS-1 (2) molecular sieves.

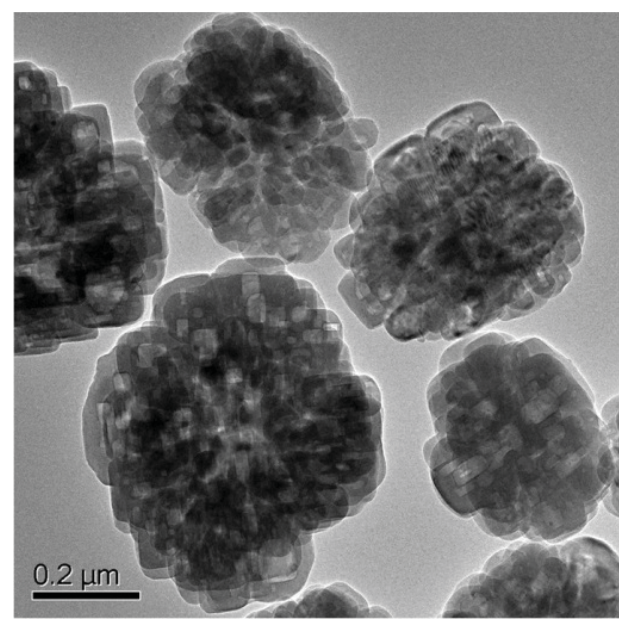

Fig. 7. TEM images of HTS molecular sieves.

figure shows that cyclohexanone conversion using HTS was almost $100 \%$, which was far higher than with TS-1, and it was stable. TS-1 showed a lower activity and deactivated quickly. At present, HTS has been used industrially in the ammoximation of cyclohexanone and it has shown good performance.

\section{Nanosized silicalite-1 synthesis and its application in the gas phase Beckmann rearrangement of cyclohexanone oxime}

The Beckmann rearrangement of cyclohexanone oxime (CHO) is an important step in caprolactam (CPL) production. The existing technology is the liquid phase Beckmann rearrangement of cyclohexanone oxime in which fuming sulfuric acid is used as the catalyst. After the reaction, the sulfuric acid must be neutralized by ammonia. This technology has been commercially used for a long time, and it is mature and caprolactam with a stable quality can be obtained. There are two problems. The first problem is that the process is not a good atom economy route because it uses high value ammonia and fuming sulfuric acid to produce less valuable ammonium sulfate. When 1 ton of caprolactam is produced, 1.6 ton of ammonium sulfate is obtained as byproduct. The second problem is the corrosion of the apparatus from using sulfuric acid in the process. Therefore, the gas phase Beckmann rearrangement of

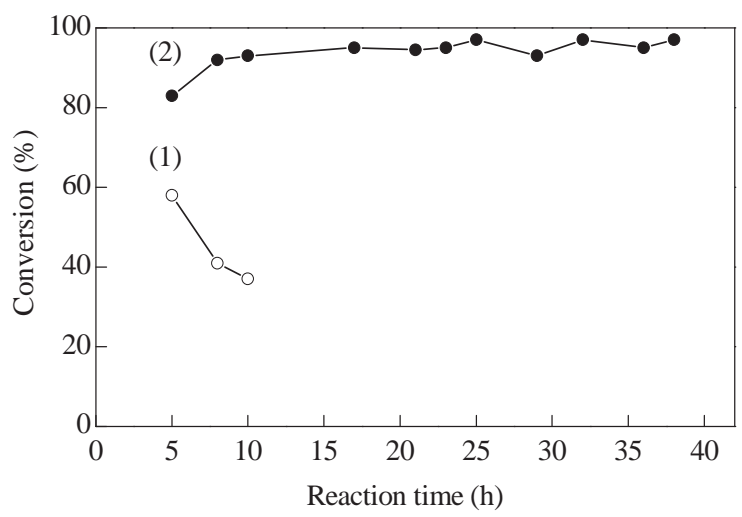

Fig. 8. Catalytic properties of conventional TS-1 (1) and HTS (2) in oximation of cyclohexanone. 
cyclohexanone oxime has been investigated since the 1980s. Among the many solid catalysts, silicalite- 1 was the best catalyst and gave a high conversion of $\mathrm{CHO}$ and good selectivity for CPL. This process does not use sulfuric acid, so there is no ammonium sulfate byproduct and no problem of corrosion. The problem is that the silicalite-1 catalyst loses activity very quickly in the process. Sumitomo solved this problem by using a fluidized bed reactor. The key to improving this technology is to prolong the lifetime of the catalyst. RIPP has developed the gas phase Beckmann rearrangement of cyclohexanone oxime based on its investigation of nanosized silicalite- 1 synthesis and application.

\subsection{Synthesis and properties of nanosized silicalite-1}

Silicalite- 1 is a pure silica zeolite with the MFI structure first reported by Flanigen from UCC in 1978 [26]. From then on, there were many investigations of it but no report of its industrial application. Silicalite-1 is usually synthesized by the hydrothermal method at $170{ }^{\circ} \mathrm{C}$ for three days using solid silica gel, silica sol, fumed silica, or TEOS as the Si source and TPAOH as the template. The problems in its synthesis are low crystallinity, large crystal size, and the presence of cations such as $\mathrm{Al}^{3+}$, $\mathrm{Na}^{+}, \mathrm{Fe}^{3+}, \mathrm{Ca}^{2+}, \mathrm{Mg}^{2+}$, etc. Recently there were many reports on silicalite-1 synthesis. The Shantz group has summarized the reports in the literature and gave information on the nucleation and crystallization of silicalite-1 from their own works [29]. Tokay et al. [30] investigated the factors that affect the particle size and its distribution in the synthesis of silicalite- 1 nanocrystals, and found that with the increasing of the template, the particle size became smaller and its distribution became narrower. From a consideration of the cost of the industrial production of silicalite-1, we synthesized nanosized silicalite-1 using a moderate amount of TPAOH in a water-ethanol system.

In order to synthesize silicalite- 1 with a small size, high crystallinity and less cations, TEOS was used as the Si source and $\mathrm{TPAOH}$ as the template in a water-ethanol system at a lower temperature. The physicochemical properties of the synthesized sample are listed in Table 3. Silicalite-1 synthesized by this method showed a larger surface area and pore volume and had only a small amount of metal ions.

Figure 9 shows the corresponding TEM image, which showed that the crystal size range was $100-200 \mathrm{~nm}$. We have now synthesized silicalite- 1 on an industrial scale, which gives a good foundation for the development of the gas phase Beckmann rearrangement of cyclohexanone oxime.

\subsection{Catalytic performance of silicalite-1 in the gas phase Beckmann rearrangement of $\mathrm{CHO}$}

The silicalite- 1 catalyst was prepared by extrusion. The op-

Table 3

Physicochemical properties of silicalite-1 molecular sieve.

\begin{tabular}{|c|c|c|c|c|c|c|}
\hline \multicolumn{3}{|c|}{ Surface area $\left(\mathrm{m}^{2} / \mathrm{g}\right)$} & \multicolumn{2}{|c|}{ Pore volume $\left(\mathrm{cm}^{3} / \mathrm{g}\right)$} & \multirow{2}{*}{$\begin{array}{c}\mathrm{Al}^{3+} \text { content } \\
\left(10^{-6}\right)\end{array}$} & \multirow{2}{*}{$\begin{array}{c}\text { Crystal } \\
\text { size (nm) }\end{array}$} \\
\hline & & & & & & \\
\hline 430 & 770 & 60 & 0.399 & & $<2$ & \\
\hline
\end{tabular}

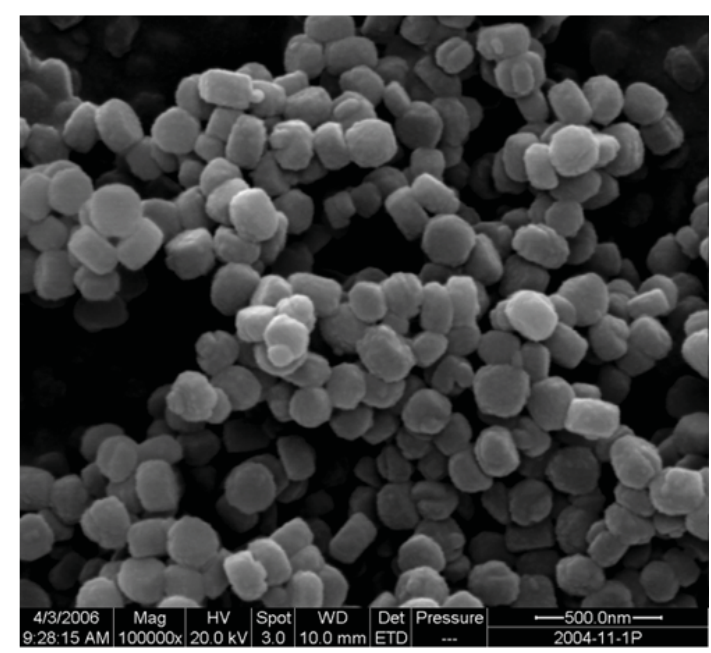

Fig. 9. TEM image of silicalite-1 molecular sieve.

erating conditions were studied and optimized [31,32]. Figure 10 gives the evaluation results from a unit with a capacity of 800 ton caprolactam annually. The major operating conditions were: temperature $350-400{ }^{\circ} \mathrm{C}$ and space velocity $1 \mathrm{~h}^{-1}$. The figure shows that the conversion of $\mathrm{CHO}$ was higher than 99.9\% and the average selectivity for CPL was $96.5 \%$ during $700 \mathrm{~h}$. These results imply that by using nanosized silicalite-1, the activity of the catalyst was maintained for a long time that was sufficient for the development of a fixed-bed technology. The pilot test of the fixed-bed gas phase Beckmann rearrangement of $\mathrm{CHO}$ has now been completed. The construction of the industrial unit is planned to be finished next year.

\section{Conclusions}

For processes in which the catalyst is deactivated easily, decreasing the size of the catalyst to the nanosize is a good way to improve the lifetime of the catalyst. The use of a nanosized ZSM-5 catalyst in straight run gasoline reforming has increased the operation period from 60 days to 90 days while maintaining a high yield of liquid product and its octane number. By using nanosized $\beta$ as the catalyst in the alkylation of benzene with ethylene, the catalyst stability was improved and the op-

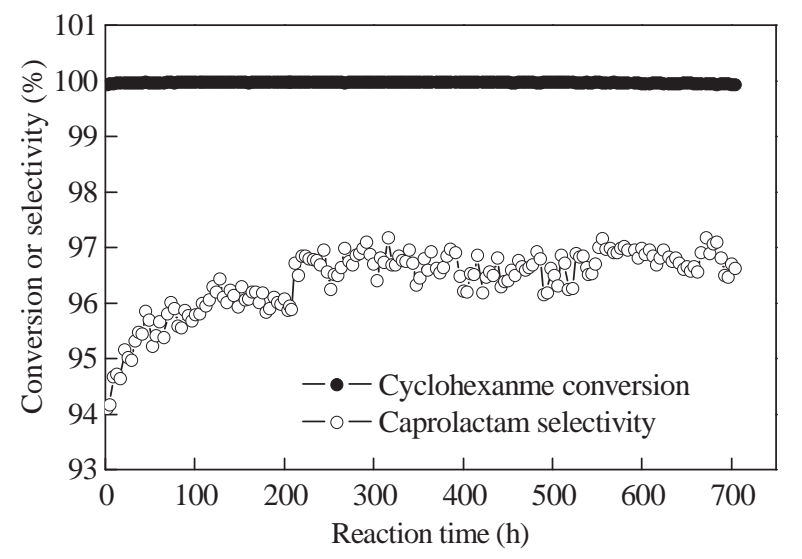

Fig. 10. Catalytic properties of nanosized silicalite-1 catalyst in Beckmann rearrangement of cyclohexanone oxime. 


\section{Graphical Abstract}

Chin. J. Catal., 2013, 34: 69-79 doi: 10.1016/S1872-2067(11)60462-2

Nanosized molecular sieves as petroleum refining and petrochemical catalysts

MU Xuhong*, WANG Dianzhong, WANG Yongrui, LIN Min, CHENG Shibiao, SHU Xingtian

Research Institute of Petroleum Processing, SINOPEC

Nanosized ZSM-5, $\beta$, HTS, and silicalite- 1 zeolites were synthesized and used, respectively, for straight run gasoline reforming, alkylation of benzene and ethylene, oximation of cylcohexanone, and gas phase Beckmann rearrangement of cylcohexanone oxime. The catalyst lifetimes were prolonged when nanosized molecular sieves were used.

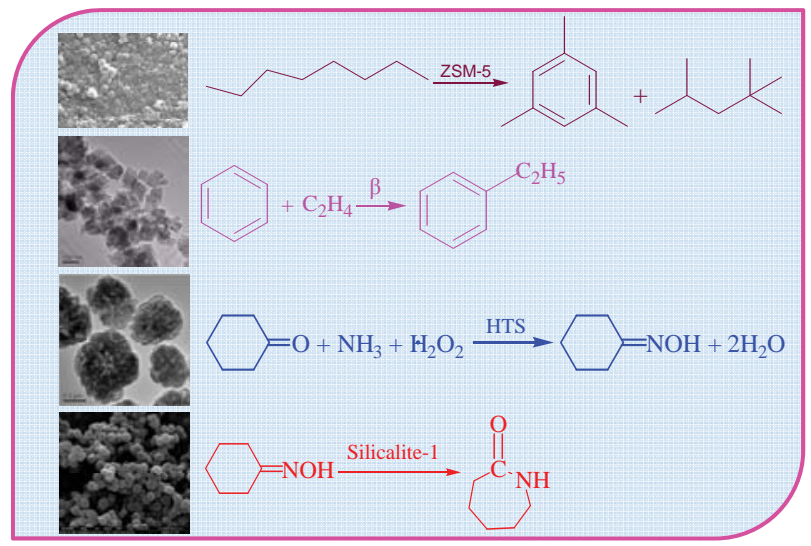

eration period in an industrial unit was increased from 3 years to 5 years. Nanosized titanosilicate molecular sieve with a hollow structure used in the ammoximation of cyclohexanone gave high conversion and a long operational time that met the requirement of industrial application well. The use of nanosized silicalite- 1 in the gas phase Beckmann rearrangement of cyclohexanone oxime gave a conversion of cyclohexanone oxime of $99.9 \%$ and the selectivity to caprolactam was $96.5 \%$ while the catalyst lifetime was maintained long enough time for operation in a fixed bed reactor.

\section{References}

[1] Degnan T. Stud Surf Sci Catal, 2007, 170: 54

[2] Wu X P, Meng X B, Lin J. Petrol Process Petrochem (吴小平, 孟宪波, 林洁. 石油炼制与化工), 2005, 36(8): 23

[3] Visvanadham N, Saxena S K, Kumar J, Sreenivasulu P, Nandam D. Fuel, 2012, 95: 298

[4] Tago T, Konno H, Sakamoto M, Nakasaka Y, Masida T. Appl Catal A, 2011, 403: 183

[5] Ni Y, Sun A, Wu X, Hai G, Hu J, Li T, Li G. Microporous Mesoporous Mater, 2011, 143: 435

[6] Miao H X, Xue Zh T, Ma J H, Zhang Y Ch, Li R F. Chin J Catal (苗海霞, 薛招腾, 马静红, 张元春, 李瑞丰. 催化学报), 2012, 33: 183

[7] Wang K Y, Wang X Sh. Ind Catal (王坤院, 王祥生. 工业催化), 2008, 16(2): 1

[8] Reding G, Maurer T, Kraushaar-Czarnetzki B. Microporous Mesoporous Mater, 2003, 57: 83

[9] Xue T, Wang Y M, He M. Microporous Mesoporous Mater, 2012, 156: 29

[10] Wang D Zh, Feng Q, Shu X T, He M Y (王殿中, 冯强, 舒兴田, 何鸣 元). CN 200410048 354. 2004

[11] Mu X H, Wang D Zh, Wang Y R, Cheng Sh B, Lin M, Shu X T. Acta Petrol Sin (Petrol Process Sect) (慕旭宏, 王殿中, 王永睿, 程时标, 林 民, 舒兴田. 石油学报 (石油加工)), 2008, 24(Suppl): 1

[12] Zhang F M, Wang J, Huang Zh Y, Li M L, He M Y. Petrol Process Petrochem (张凤美, 王瑾, 黄志渊, 李明林, 何鸣元. 石油炼制与化工), 2000, 31(5): 37

[13] Wang J, Zhang F M, Li M L, Zhang Ch. Petrol Process Petrochem (王
瑾, 张凤美, 李明林, 张赪. 石油炼制与化工), 2002, 33(9): 13

[14] Hao X M, Zhang F M, Wang J. Chem Ind Eng Progr (郝小明, 张凤美, 王瑾. 化工进展), 2003, 22: 920

[15] Majano G, Mintova S, Ovsitser O, Mihailova B, Bein T. Microporous Mesoporous Mater, 2005, 80:227

[16] Sakthivel A, Iida A, Komura K, Sugi Y, Chary K R. Microporous Mesoporous Mater, 2009, 119: 322

[17] Liu Sh P, Yue M B, Wang Y M. Acta Phys-Chim Sin (刘树萍, 岳明波, 王一萌. 物理化学学报), 2010, 26: 2224

[18] Thangaraj A, Sivasanker S, Ratnasamy P. J Catal, 1991, 131: 394

[19] Wang M Zh, Lin M, Zhu B. Chem Ind Eng Progr (王梅正, 林民, 朱 斌. 化工进展), 2007, 26: 1258

[20] Xie W, Liu Y M, Wang L L, Wu P. Chin J Catal (谢伟, 刘月明, 汪玲 玲, 吴鹏. 催化学报), 2010, 31: 502

[21] Lakiss L, Rivallan M, Goupil J M, Fallah J, Mintova S. Catal Today, 2011, 168: 112

[22] Cheneviere Y, Chieux F, Caps V, Tuel A.J Catal, 2010, 269: 161

[23] Serrano D P, Sanz R, Pizarro P, Moreno I. Appl Catal A, 2012, 435-436: 32

[24] Lin M, Shu X T, Wang X Q. Acta Petrol Sin (Petrol Process Sect) (林 民, 舒兴田, 汪萃卿. 石油学报 (石油加工)), 2003, 19(3): 33

[25] Lin M, Shu X T, Wang X Q. Petrol Process Petrochem (林民, 舒兴田, 汪潁卿. 石油炼制与化工), 2003, 34(10): 38

[26] Wang Y, Lin M, Tuel A. Microporous Mesoporous Mater, 2007, 102: 80

[27] Zhu B, Lin M, Shu X T, Shi Ch F. Acta Petrol Sin (Petrol Process Sect) (朱斌, 林民, 舒兴田, 史春风. 石油学报 (石油加工)), 2009, (S2): 112

[28] Baerlocher C, McCusker L B, Olson D H eds. Atlas of Zeolite Framework Types. Amsterdam: Elsevier, 2007. 212

[29] Rivas-Cardona A, Chovanetz M, Shantz D F. Microporous Mesoporous Mater, 2012, 155: 56

[30] Tokay B, Erdem-Senatalar A. Microporous Mesoporous Mater, 2012, 148: 43

[31] Cheng Sh B, Zhang Sh Zh, Wu W, Min E Z. Acta Petrol Sin (Petrol Process Sect) (程时标, 张树忠, 吴巍, 闵恩泽. 石油学报 (石油加 工)), 2006, 22(2): 14

[32] Cheng Sh B, Zhang Sh Zh, Wu W, Min E Z. Acta Petrol Sin (Petrol Process Sect) (程时标, 张树忠, 吴巍, 闵恩泽. 石油学报 (石油加 工)), 2006, 22(1): 33 


\title{
纳米分子篮在炼油和石油化工中的应用
}

\author{
慕旭宏"，王殿中，王永睿，林民，程时标，舒兴田 \\ 中国石化石油化工科学研究院, 石油化工催化材料与反应工程国家重点实验室, 北京 100083
}

\begin{abstract}
摘要: 介绍了纳米ZSM-5 分子篮的合成及其在直馏汽油非临氢改质中的应用、纳米 $\beta$ 分子篎的合成及其在苯与乙烯液相烷基化 中的应用、纳米空心钛硅分子篮 (HTS) 的合成及其在环己酮氨肟化过程中的应用以及纳米 Silicalite-1 分子篮的合成及其在环己酮 肟气相贝克曼重排生产己内酰胺中的应用, 并简要综述了上述纳米分子篮合成和应用方面的最新研究进展. 结果表明, 对于炼油 和石油化工中易结焦失活的催化反应过程, 分子篮的纳米化可抑制催化剂快速失活, 延长催化剂寿命.
\end{abstract}

关键词: 纳米分子篮; ZSM-5; $\beta$; 钛硅分子篮; Silicalite-1; 汽油改质; 乙苯; 己内酰胺

收稿日期: 2012-07-25. 接受日期: 2012-09-24. 出版日期: 2013-01-20.

*通讯联系人. 电话: (010)82368237; 传真: (010)62311290; 电子信箱: muxuhong.ripp@ sinopec.com

基金来源: 国家重点基础研究发展计划 (973 计划,2012CB224805).

本文的英文电子版由Elsevier出版社在ScienceDirect上出版(http://www.sciencedirect.com/science/journal/18722067).

\section{1. 前言}

作为催化剂活性组分, 分子篮已广泛应用于催化裂 化、加氢裂化、汽柴油改质、润滑油加氢处理、烯烃齐 聚、轻烯烃生产、二甲苯异构化、芳烃歧化、乙苯和异 丙苯生产、不饱和烃氧化等炼油和石油化工过程 ${ }^{[1]}$. 其中 纳米分子篮的单个晶粒尺寸较小, 暴露在外表面的活性 中心较多,因此催化活性一般较高; 同时,由于晶粒较小, 孔道变短,有利于反应物和产物分子的扩散, 从而提高了 某些反应的选择性, 延缓了结焦失活. 因此, 分子篮纳米 化是分子篮合成和应用研究领域的一个重要方向. 中国 石化石油化工科学研究院 (以下简称石科院) 从上世纪 90 年代后期就开展了 Y, ZSM-5 和 $\beta$ 等分子篮的纳米化 合成和应用研究, 解决了纳米分子篮难于合成、难于回 收和难于分散等问题, 并实现了一些分子篮在石油化工 过程中的应用. 本文主要介绍了纳米ZSM-5 分子篮的合 成及其在直馏汽油非临氢改质中的应用、纳米 $\beta$ 分子篮 的合成及其在苯与乙烯烷基化中的应用、纳米空心钛硅 分子篮 (HTS) 的合成及其在环己酮氨肜化过程中的应用 以及纳米 Silicalite-1 分子篮的合成及其在环己酮肜气相 贝克曼重排生产己内酰胺中的应用.

\section{2. 纳米 ZSM-5 分子篮的合成及其在直馏汽油非 临氢改质中的应用}

直馏汽油非临氢改质是指在催化剂的作用下, 直馏 汽油和碳四组分通过选择性裂解、异构、叠合、环化和 芳构化等一系列复杂的化学反应, 转化为低烯烃含量的 高辛烷值汽油和优质液化气的过程 ${ }^{[2]}$. 该过程所用催化 剂一般是 ZSM-5 分子篮,但存在稳定性差、操作周期较
短 (一般为 122 月) 的问题. 这主要是由于结焦失活所致. 近年来有关通过降低 ZSM-5 分子篮晶粒大小来提高活 性和延长催化剂寿命的报道较多. Visvanadham 等 ${ }^{[3]}$ 通 过减小 ZSM-5 分子篮晶粒尺寸至亚微米范围, 显著延长 了催化剂在乙醇脱水制乙烯中的寿命. Tago 等 ${ }^{[4]}$ 采用微 乳法制备了 30 40 nm 的ZSM-5 分子篎, 并将其用于丙酮 制轻烯烃过程; 与大晶粒 ZSM-5 相比, 该样品表现出很 高的活性, 且寿命大大延长. $\mathrm{Ni}^{\text {等 }}{ }^{[5]}$ 发现采用常规 ZSM-5 分子筛催化剂进行甲醇芳构化时结焦速度快, 催化剂寿 命较短; 而以纳米 ZSM-5 为催化剂时, 结焦速度变慢, 催 化剂寿命显著延长. 苗海霞等 ${ }^{[6]}$ 采用沸石晶种有机硅烷 化法合成了纳米团簇 ZSM-5 分子篮, 与常规 ZSM-5 相 比, 减小了空间位阻, 对于较大分子 1,3,5-三甲苯的苠基 化反应表现出良好的催化活性. 考虑到分子篮纳米化后, 孔道缩短, 暴露在外面的活性中心数目多, 有利于产物分 子的扩散, 从而延长催化剂寿命, 因此我们开展了纳米 ZSM-5 合成和用于直馏汽油非临氢改质过程的研究.

\section{1. 纳米 ZSM-5 分子篮的合成和物化性质}

控制分子篮合成过程中的成核速度和成长速度的 比值可调变分子篮晶粒大小: 如果成核速度高于成长速 度就可合成出小晶粒分子篮. 人们提出了多种方法来合 成纳米 ZSM-5 分子篎, 如调节晶化温度、晶化时间、碱 金属和模板剂用量来控制晶粒大小; 用有机硅铝源、低 温晶化的清液和微乳法, 限度空间分子篎合成法等 ${ }^{[3-9]}$. 考虑到后两种合成方法成本较高, 石科院采用分段晶 化、添加晶种以及控制成核温度和晶化温度等方法合成 出了纳米 ZSM-5 分子篮 ${ }^{10]}$.

表 1 对比了纳米 ZSM-5 分子篮与常规 ZSM-5 分子 篮的比表面积和孔体积. 可以看出, 纳米 ZSM-5 分子笛 
比表面积, 尤其是外比表面积明显高于常规 ZSM-5 分子 笁, 微孔体积相近而总孔体积较大. 这说明纳米分子篮 晶粒小, 存在许多堆积孔.

图 1 是纳米 ZSM-5 的扫描电镜 (SEM) 照片. 可以看 出, 分子篮粒度分布较均匀, 晶粒大小约 50 100 nm

\section{2. 纳米 ZSM-5 分子篮上直馏汽油非临氢改质反应} 性能

图 2 是纳米 ZSM-5 分子篮用于直馏汽油非临氢改 质过程的催化性能, 反应条件为: 质量空速 $0.3 \sim 0.5 \mathrm{~h}^{-1}$, 温 度 $320 \sim 440{ }^{\circ} \mathrm{C}$, 压力 $0.2 \sim 0.4 \mathrm{MPa}$. 可以看出, 与常规 ZSM-5 分子篮相比, 当液体产物收率 $\left(\mathrm{C}_{5+}\right)$ 和辛烷值 (RON) 接近时, 纳米 ZSM-5 分子篮的初始反应温度明显 降低, 温度操作区间增加, 操作周期从 60 多天提高到 90 天以上.

\section{3. 纳米 $\boldsymbol{\beta}$ 分子篮的合成及其在苯与乙烯烷基化 中的应用}

乙苯是生产苯乙烯的原料, 早期的乙苯生产技术是 $\mathrm{AlCl}_{3}$ 法, 由于污染环境, 因而被以 $\mathrm{ZSM}-5$ 为催化剂的气 相法乙苯技术取代. 后来又开发了以 $\beta$ 分子篮和 MCM-22 分子篮为活性组元的液相法乙苯技术. 催化剂 活性组元的不断改进使得乙苯技术的能耗和物耗不断 下降, 产品质量不断提高, 催化剂寿命不断延长. 石科院 从1990年开始研究开发液相法乙苯合成催化剂和工艺, 研制出了以 $\beta$ 分子篎为活性组元的 AEB-2 型苯和乙烯 液相烷基化催化剂 ${ }^{[12 ~ 14]}$. 为了进一步提高苯与乙烯烷 基化催化剂活性, 延长催化剂寿命, 开展了纳米 $\beta$ 分子篮 的合成及其在苯与乙烯液相烷基化应用的研究.

\section{1. 纳米 $\beta$ 分子篮的合成和物化性质}

纳米 $\beta$ 分子篎合成研究始于上世纪 90 年代, 早期主 要通过使用有机硅铝源、提高模板剂用量和降低晶化温 度等方法以降低晶粒大小, 近年来也出现蒸气辅助合成 法 $^{[15]}$ 和干胶合成法 ${ }^{[16]}$ 等新方法, 还有磷酸盐辅助合成富 含介孔的纳米 $\beta$ 分子篮组装体的报道 ${ }^{[17]}$. 石科院采用固 体硅胶为硅源, 偏铝酸钠为铝源, TEAOH 为模板剂合成 了 $\beta$ 分子篮. 合成过程中, 部分固体硅胶在碱性条件下解 聚为多硅酸根离子, 在模板剂作用下与铝酸根离子结合, 在晶化条件下发生缩聚, 形成分子䇥晶核; 然后, 随着固 体硅胶持续解聚, 多硅酸根离子不断补充到晶化区域, 在 晶核表面形成短程有序的 $\beta$ 分子篮前驱物; 最后, 晶核成 长为分子篮晶体. 为了降低 $\beta$ 分子篮晶粒大小, 采用分段 晶化法进行低温成核和高温晶化; 同时,通过控制硅胶
原料的聚合状态, 使其在碱性条件下, 容易解聚为多硅酸 根离子, 并与铝酸根离子迅速发生缩聚反应, 使分子篮的 晶核在短时间内大量生成, 成核速率大于成长速率, 从而 得到纳米级 $\beta$ 分子篮.

表 2 列出了纳米 $\beta$ 分子篮的比表面积和孔体积, 并 与常规 $\beta$ 分子篮进行了对比. 可以看出, 纳米 $\beta$ 分子篮的 比表面积和孔体积均显著高于常规 $\beta$ 分子篮, 外表面积 也较大, 说明其晶粒较小. 图 3 的透射电镜 (TEM) 照片也 验证了这一结果.

图 4 是用 $X$ 射线能谱分析 (EDX) 测得的 6 个不同纳 米 $\beta$ 分子筱颗粒沿对角线方向不同位置的硅铝比, 图中 横坐标 1 和 8 表示颗粒对角线的两个端点, 2 到 7 表示对 角线七等分的不同位置点, 纵坐标为所对应的硅铝比. 由图可见, 分子篮颗粒表面硅铝比较高, 而中心硅铝比较 低, 说明该方法合成的纳米 $\beta$ 分子篮具有表面富硅的特 点.

\section{2. 纳米 $\beta$ 分子篮在苯与乙烯烷基化反应中的催化性} 能

在高压微反装置上对纳米 $\beta$ 分子篮和常规 $\beta$ 分子篮 催化苯和乙烯烷基化反应性能进行了评价. 反应条件为: 催化剂粒度 16 20目, 装量 $8 \mathrm{ml}$, 反应温度 $250^{\circ} \mathrm{C}$, 反应压 力 $3.5 \mathrm{MPa}$, 在苯体积空速 $3 \mathrm{~h}^{-1}$, 苯/乙烯摩尔比 12 条件 (条件 1) 下评价 $100 \mathrm{~h}$, 然后在苯空速 $12 \mathrm{~h}^{-1}$, 苯/乙烯摩尔 比 18 的条件 (条件 2)下继续评价, 结果见图 5. 由图可见, 对于纳米 $\beta$ 分子篮催化剂, 条件 1 时, 乙烯转化率为 $100 \%$, 乙苯选择性平均为 $95.4 \%$, 乙基化选择性为 $99.4 \%$; 条件 2 时, 乙烯转化率为 $100 \%$, 乙苯选择性平均为 $96.7 \%$, 乙 基化选择性为 $99.5 \%$. 而对于常规合成 $\beta$ 分子篮催化剂, 条件 1 时, 乙烯转化率为 $100 \%$, 乙苯选择性平均为 $95.4 \%$, 乙基化选择性为 $99.4 \%$; 条件 2 时, 乙烯转化率为 $100 \%$, 乙苯选择性平均为 $96.9 \%$, 乙基化选择性为 $99.5 \%$. 可见两种催化剂性能相当,但纳米 $\beta$ 分子篮的运转周期 更长. 目前, 以纳米 $\beta$ 分子篮为活性组元的乙苯合成催化 剂已用于工业装置, 表现出很好的催化性能, 其操作周期 从 3 年延长到 5 年.

\section{4. 纳米空心钛硅分子篮 HTS 的合成及其在环己 酮氨肜化过程中的应用}

己内酰胺是一种重要的化工单体, 主要用于生产尼 龙 6 工程塑料和尼龙 6 (锦纶) 纤维, 其中锦纶纤维广泛应 用于毛纺、针织、机织、窝子布、地毯等行业, 尼龙 $6 工$ 程塑料广泛应用于电子、汽车、包装薄膜等行业. 随着 
我国汽车和纺织工业的快速发展, 己内酰胺需求量不断 增长. 已内酰胺生产包括苯加氢变为环已烷、环已烷氧 化变为环已酮、环己酮肜化变为环已酮肜、环已酮肜重 排变为己内酰胺以及己内酰胺精制等步骤. 传统的环己 酮肟生产方法主要是磷酸着弪胺法, 环己酮通过 4 步反应 得到环己酮肟. 该技术不仅流程复杂, 而且存在 $\mathrm{NO}_{x}$ 排 放. 意大利EniChem 公司合成出了钛硅分子篮(TS-1), 并 以此为催化剂, $\mathrm{H}_{2} \mathrm{O}_{2}$ 为氧化剂, 与环己酮和氨一步反应 得到环己酮肜. 此过程环境友好, 但存在催化剂失活快 的问题, 这是由于堵孔失活所致 ${ }^{[18,19]}$. 催化剂一旦失活, 主反应活性下降很快, 而副反应 $\mathrm{H}_{2} \mathrm{O}_{2}$ 分解加剧, 造成很 大安全隐患. 石科院从分子篮合成角度, 通过控制钛硅 分子篮晶粒大小和形貌, 开展了相关研究.

\section{1. 纳米空心钛硅分子篮 HTS 的合成和物化性质}

TS- 1 在上世纪 80 年代问世以后, 人们对其合成开展 了大量的研究, 但由于钛与硅在原子半径和电子结构等 方面存在显著差异, 合成时钛很难进入分子篮骨架, 导致 合成重复性差, 难以得到催化活性高、性能稳定的产品, 且因 TS-1 知识产权制约, 尽管各国都投入力量研究, 但 除意大利 EniChem 公司外, 鲜有公司掌握其生产和应用 技术. TS-1 分子篮具有良好的催化氧化性能, 但由于其 孔径较小, 表现出明显的传质限制, 影响了催化剂寿命, 也限制了它的广泛应用. 因此, 人们开展了较大孔径含 钛分子篮的合成和应用研究, 如 Ti-MWW, Ti- $\beta$, Ti-MCM-41 和 Ti-SBA-15 等, 发现具有 MWW 结构的钛 硅分子篮孔道结构可塑性强, 通过采用层间剥离、柱撑 以及分子水平硅烷化插硅扩孔技术, 可以增大和暴露孔 道和外表面, 满足不同氧化反应的要求 ${ }^{[20]}$, 而后三种含 钛分子篮水热稳定性差, 本征催化活性较低. 近年来, 有 关微孔介孔多级孔结构 TS-1 分子篮材料合成和应用的 报道较多. 该分子篮的合成一般使用造孔剂或控制蒸发 制造介孔 ${ }^{[21]}$, 最近也有加硅烷化试剂通过二次晶化方法 制备多级孔 TS- 1 的报道 ${ }^{[22,23]}$. 石科院采用晶化和后处理 方法制备了具有空心结构的纳米钛硅分子篮 (HTS). 通 过对合成机理研究 ${ }^{[24-27]}$, 提出硅钛酯匹配水解和脱醇成 核新思路, 通过硅钛酯适度水解, 使产生硅钛低聚物速率 和程度相互匹配, 应用醇转移和有机碱的模板作用成核, 用变温晶化控制晶粒分步生长, 将钣硅分子篮晶粒控制 在 $100 \mathrm{~nm}$ 之内; 同时, 提出了重排方法, 即钛硅分子篮合 成中间体在胺类化合物和表面活性剂等助剂水热作用 下, 促进硅钛羟基缩合, 使非骨架钛进入骨架, 增加了活 性中心, 保证了合成的重复性, 同时形成了形貌独特的晶
内空心结构. 纳米尺寸晶粒和空心结构均有利于反应物 和产物的扩散,可有效抑制催化剂堵孔失活.

图 6 是纳米级并具有空心结构的新型钛硅分子篮 HTS 和常规 TS- 1 的低温 $\mathrm{N}_{2}$ 吸附-脱附等温线. 由图可见, HTS 钛硅分子篮等温线存在明显的滞后环, 而常规 TS- 1 则没有. 这说明 HTS 存在大量介孔, 而常规 TS- 1 主要是 微孔.

HTS 分子篮晶粒较小, 直接作为环己酮氨肟化催化 剂可解决扩散问题,延长催化剂寿命, 但在工业使用时难 以分离回收, 因此通过调节合成体系性质, 使 HTS 一次 粒子聚集为较大颗粒. 图 7 是 HTS 聚集形成较大颗粒的 TEM 照片. 可以看出, HTS 分子篮一次粒子均为几十纳 米, 而且晶体中存在明显的空心结构, 这也是其吸附等温 线存在滞后环的原因; 聚集后颗粒尺寸为 300 500 nm, 且分布较均匀, 较易分离回收.

\section{2. 纳米空心钛硅分子篮 HTS 催化环己酮氨肜化性能}

图 8 是 HTS 钛硅分子節用于环己酮氨肜化过程的 环己酮转化率随时间的变化曲线, 并与常规 TS- 1 进行了 对比. 评价条件为: 反应温度 $83^{\circ} \mathrm{C}$, 压力 $0.4 \mathrm{MPa}$. 可以看 出, HTS 钛硅分子篮的环已酮转化率接近 $100 \%$, 显著高 于 TS-1, 且具有较好的活性稳定性, 而 TS-1 的环已酮转 化率随时间的延长而明显下降. 目前, HTS 已在环已酮 氨肜化工业装置中使用, 表现出良好的催化性能.

\section{5. 纳米 Silicalite-1 分子篮的合成及其在环己酮 肟气相贝克曼重排中的应用}

环己酮肜贝克曼重排反应是生产己内酰胺的重要 步骤, 目前普遍采用液相贝克曼重排技术, 即在发烟硫酸 的催化作用下, 发生贝克曼重排反应, 再进一步与氨中和 得到己内酰胺和硫酸铵. 此工艺技术成熟, 产品质量稳 定, 但存在两大问题: (1) 消耗经济价值较高的氨和发烟 硫酸, 副产大量低价值硫酸铵,生产 1 吨已内酰胺约产生 1.6 吨硫酸铵; (2) 存在设备腐蚀和环境污染. 从上世纪 80 年代起, 人们开始研究气相贝克曼重排工艺. 通过对 多种催化剂的研究发现, 以纯硅分子篮 Silicalite-1 为催 化剂, 环己酮肜转化率和已内酰胺选择性最好. 采用该 催化剂可使环己酮肜一步转化为己内酰胺. 由于不使用 硫酸, 不副产硫酸铵, 也不存在腐蚀问题, 工艺过程环境 友好, 但催化剂失活较快. 日本住友公司开发了流化床 技术, 解决了连续化操作问题. 如何延长气相重排过程 中催化剂的寿命是技术开发的关键. 石科院通过活性组 元的纳米化推动了气相重排技术的开发. 


\section{1. 纳米 Silicalite-1 分子篮的合成和物化性质}

Silicalite-1 分子篮是一种具有 MFI 拓扑学结构的全 硅分子篮, 是 UCC 公司在 1978 年首次合成出来的 ${ }^{[28]}$, 但一直未得到应用. 该分子篮一般采用水热法合成, 硅 源可选用固体氧化硅、硅溶胶、白炭黑和正硅酸乙酯等, 模板剂多采用四丙基氢氧化铵、低碳烃类季铵盐或两者 混合物及胺类化合物等, 在 $170^{\circ} \mathrm{C}$ 晶化 $3 \mathrm{~d}$. Silicalite- 1 分 子篮合成中存在的主要问题是相对结晶度较低, 含无定 形氧化硅较多, 晶体颗粒较大, 并含有微量的 $\mathrm{Al}^{3+}, \mathrm{Na}^{+}$, $\mathrm{Fe}^{3+}, \mathrm{Ca}^{2+}$ 和 $\mathrm{Mg}^{2+}$ 等金属离子. 有关 Silicalite-1 合成的报 道很多. Shantz研究组最近总结了前人的工作, 同时深入 研究了其成核和晶化机理 ${ }^{[29]}$. Tokay 等 ${ }^{[30]}$ 考察了影响晶 粒大小的主要因素, 发现模板剂用量越大, 晶粒越小, 其 分布也越窄. 考虑到工业应用中对分子篮生产成本的要 求, 我们采用适量模板剂在醇水混合体系中合成了纳米 Silicalite-1 分子篎.

为了合成高结晶度、小晶粒、无金属离子的 Silicalite-1 分子篮, 采用正硅酸乙酯作硅源, 四丙基氢氧化 铵作模板剂, 在水-醇热体系中, 较低温度下合成了 Silicalite-1 分子篮, 其物化性质见表 3. 可以看出, 该分子篮 比表面积和孔体积较大,金属离子含量很低.

图9 是 Silicalite-1 分子篮的 TEM 照片. 由图可见, 样 品为球状, 结晶完整, 粒度均匀, 晶粒大小为 $100 \sim 200 \mathrm{~nm}$. 目前, Silicalite-1 分子篮已实现了工业生产,物化性质稳 定, 为开发环己酮肜气相贝克曼重排技术奠定了基础.

5.2. 纳米 Silicalite-1 分子篮为活性组元的环己酮肜气

\section{相贝克曼重排催化剂催化性能}

以 Silicalite-1 分子篮为活性组元, 通过挤条成型制 得催化剂,进行了反应条件优化 ${ }^{[31,32]}$, 在 800 吨/年环己酮 肜气相贝克曼重排工业侧线装置上进行了催化性能评 价, 图 10 给出了环已酮肜转化率和已内酰胺选择性随反 应时间的变化关系. 评价条件为: 反应温度 $350 \sim 400^{\circ} \mathrm{C}$, 空速 $1 \mathrm{~h}^{-1}$. 由图可见, 反应运行 $700 \mathrm{~h}$ 以上, 环已酮肜转化 率达到 $99.9 \%$ 以上, 已内酰胺平均选择性为 $96.5 \%$ 左右. 这说明通过合成纳米 Silicalite-1 分子篮, 提高了催化剂 稳定性, 满足了固定床气相重排工艺的需要. 目前, 固定 床环己酮肟气相贝克曼重排技术已完成中试, 进入工业 化阶段.

\section{6. 结论}

通过合成纳米 ZSM-5 并用作直馏汽油非临氢改质 催化剂, 在保持较高液体产物收率的情况下, 反应温度明 显降低, 操作周期从 60 多天延长到 90 天. 通过合成纳米 $\beta$ 分子篮并用作苯与乙烯液相烷基化催化剂, 乙烯转化 率、乙基化选择性和乙苯选择性与常规 $\beta$ 分子篮催化剂 的相当, 但活性稳定性增加, 工业催化剂操作周期由 3 年 延长到 5 年. 通过合成纳米空心结构铁硅分子篮 (HTS), 用于环己酮氨肜化过程表现出很高的转化率和较长使 用寿命, 满足了工业应用. 通过合成纳米 Silicalite-1 分子 篮并用于环己酮肜气相贝克曼重排催化剂, 环己酮肟转 化率达到 $99.9 \%$, 己内酰胺选择性达到 $96.5 \%$, 并且能维 持较长使用寿命, 满足了固定床工艺的要求. 